DOI https://doi.org/10.36059/978-966-397-108-7/165-184

\title{
THE HISTORICAL DETERMINACY OF MORALITY
}

\section{Tymoshenko T.S.}

The historical determinacy of morality is revealed in a historic retrospective, namely, during consideration of ancient ethics from Socrates and Plato as such, that did not distinguish the morality as an individual domain but it was a teaching about a certain person's attitude to things, diverse changes in destiny and, fist of all, to the own self. Later on, Democritus saw a person in their activity aimed at state interests and public justice. Plato and Aristotle consider social nature and the purpose of human morality and moral activity as a means of public and political phenomena, since it is such approach that was required by their epoch. Middle Ages, the Renaissance, the Enlightenment, and the Modern era requires new approaches to the interaction between morality and politics, associated with the requirements of the time as well as appropriate moralpolitical reference points as a stabilizing paradigm of organization of public-political life, first of all, determined by the human activity.

In the process of development and formation of philosophic knowledge, ambiguity of morality interpretation in the regulation of relations and connections in the society, in spiritual and political domain of personality activity has been determined. The problem is not only in the fact that there are some differences in methodological and worldview approaches to the morality analysis, but in fundamental peculiarities of theoretical human cognition of socio-political processes being the key factor when considering the morality essence and functions. Such processes may be stated by an objective way only in case of their subject embodiment, as certain content, genetically correlated with the subject. For example, if we speak about the process of material production cognition, the procedure of activity is rather formalized and thus it is remote from the executor. The product gains a single and practically verified function, and there are no difficulties in this case. In the case of morality, the conditions of activity acts and functional identity of activity outcomes are not followed. Firstly, it is determined by the fact that morality is, first of all, a creative domain, but not reproductive activity 
and therefore, the development of a formalized program for production of a certain behavior has no essential meaning. Secondly, objective embodiment of moralistic activity products in the most part of functional specialization is focused on sensual contemplation; the so-called internal work of "consumption" of moral norm, principle, regulations etc. in public life and public-political activity is carried out. The formal qualities of moralistic norms are getting connected meaningfully neither with one nor with another external necessity established, but with the whole world of the person and a set of their life endeavors.

Therefore, a human ability of moralistic regulation of their behavior is in the basis of moralistic activity as well as its satisfying need, hidden in the depth of internal human world and unlike the class of functional needs it is not revealed itself literally. The necessity in need and interest will be the line of determination originated from the subjects' nature and their interaction with social environment.

The needs play a decisive rope in the general system of social regulation of human behavior; they have sole general methodological meaning for revealing the complicated mechanism of mechanistic regulation of human behavior. The need is the form of transformation of objective necessity into subjective stimuli. Traditionally, objective necessity is considered as something externally relative to subjectivity and freedom, or as a boundary, limiting the relative freedom. Such type of necessity appears external and coercive condition of human activity and is, in essence, aimed at neutralizing, using or adapting to it. In relation to such necessities, the human needs act as externally opposite. There is also another type of opposition. The necessity is intrinsic for the life activity of society, a person, determined by their biological and socio-historical nature. Therefore, it reveals the need of a person, society, existence of certain phenomena, principles and transformations. Such necessity manifests itself as the need of the subject.

Comparing cognition need with objective ability and personal skills, the subject makes a decision themselves which subject or relations exactly satisfy their needs. The diversity of human needs determines a variety of meaningful interests and activities aimed at their satisfaction. Any life meaning of interests and human needs reflected in them, as well as awareness this significance is laid by the subjects before the foundation of moral values foundation that is in mind. Such spiritual institution plays a 
role of a life guideline, a spiritual basis for choice of practical and cognitive activity directions and goal subordination.

Philosophical ideas about the world have never been a simple description, indifferent representation of external reality picture. It had a certain attitude of contemplating the world subject in itself; it revealed one or another human attitude to everything that existed, thus, the philosophy put a question on relation of a subject to an object, consciousness to human existence as a thinking and acting subject to the world in general. The problem of the person's place in the world and public reality is understood as holistic-universal interdependence and interaction, its active-subjective attitude to the world in material and spiritual practice. Under the "person's place" we understand not only the material influences and transformations that a person can make in surrounding reality, but, first of all, a human ability to be the subject in their material and spiritual actions, in the historical process of the world cognition.

The subjectivity of a person was considered differently in the history of philosophy, in particular, in the form of space exploration by the person that in the ancient Greek lexis is expressed by the concept of "logos"; involvement of a person in the logic of absolute idea that can be seen in Hegel. By one way or another, general-philosophic concepts and ideas about universum were a means of human consciousness, perception own self in the world and the meaning of the world to themselves at the same time, and thus any philosophic system unlike certain science was the representation of a certain life attitude. Word perception in philosophy is not only one or another angle or perspective of view; it is most probably active-subjective practical guidelines and orientations.

It is this circumstance that differentiates philosophic worldview from moral idea. Finally, any form of the concept: good, evil, justice, ideal expresses human attitude to perception or objection of the reality. Both practical nature of moral consciousness and philosophic attitude have a difference. Dual connection of one with another is manifested externally in the very speech of philosophy and morality. Normative modality, value-provisional justifications about activity and action is typical of the moral idea. Philosophy, in turn, deals with the concepts of substance and essence, objective law and the necessity. However, it is that difference with all absoluteness of law that formed a problem in philosophic history 
that it was necessary to put and solve in order to establish own sovereignty in the world of the human spirit.

Just like morality, religion is striving to give (and it gives) an evaluation for human relationships and behavior in the controversial interlacement of good and evil. Just like art, religion widely uses the right to aesthetic covering and determining the reality, it involves artistic activity in its area. It seems that such situation washes out the subject of religion consciousness. However, in reality, it interprets the latter. According to manifestations of the natural and human world the religion sees their creator or God as fundamental principle and fundamental cause of existence. The subject of religion spirituality is God and all his manifestations. There is the first specific distinction of religion from other ways of spiritual-practical world exploration.

The ways of spiritual-practical exploration of reality perform various functions, a social role in public daily activity of people. So, the science is called for life by human endeavor to the objective truth. The main purpose of morality is regulation of public relations. Art awakes a person to creative work, lifts their spirit, and ennobles sensuality. Religion calms a person down, bringing them to contemplation of eternal, divine things.

Belief released the activity, motivated a person to act under the conditions when a present knowledge did not cover more than adequate awareness of the environment. "Belief, - P. Kopnin says in connection with it, - is an ability of a person to go beyond the limits of something that exists, to acknowledge the presence of something that is difficult to achieve. Belief, assurance does not only contradict the truth of science but also originates from it; it is also the exit of a person beyond immediately given in knowledge, but such exit that has a real basis in the knowledge itself" . Limitedness of knowledge restrained practical activity; belief (in a real possibility of the desired) released, stimulated, activated it. Belief gave a person confidence in the truth of idea that they were trying to transfer into reality. Confidence awakened the will, purposefulness, emotional energy, and excitement. It was the latter that appeared to be the drop that overfilled a cup and motivated to pass from spirit to action, from thought (idea) of reality to active practical activity. As V. Shynkaruk emphasizes, the positive quality of belief manifests itself precisely in its ability to detect and realize the hidden ability in a person to do something

\footnotetext{
${ }^{1}$ Копнин П.В. Гносеологические и логические основы науки. - М.: Мысль, 1974. - 565 с.
} 
that seems to be impossible. It inspires a person, lifting them over the circumstances. Belief appears as a psychological orientation, as the perception of probable knowledge as authentically true. It is "genetically connected with goal-based creative activity, includes vision and prediction of the future, but as an assumption."2.

In contrast to the value worldview, philosophy must explain the existence of evil, and then reconcile the fact of its existence with the "reasonableness" of the world order. So there are many attempts to justify the need for evil: a) an explanation of the differences between reasonableness of "logos" as all-permeating necessity of the world order and the presence of unhappiness, evil and drawbacks in the world, in the Stoics; b) the concept of evil fate, as the test sent to people, in the Roman stoics; c) tradition of combining the idea of omnipotent and good God with the presence of evil in human life in Christian theology, in a temporal philosophy of Leibniz; d) the ratio of good and reasonable results of history with a positive and creative role of evil origin in the very historical movement - Kant considers this problem in the "Ideas of universal history"; e) Hegel interprets the coincidence of final results of personally selfish will with the reasonableness of prediction as a manifestation of "tricks of the world spirit". Life is complex, multifactorial, and unique. History can not be turned back too. Hence, there is the responsibility for the choice, activity, for own destiny. A person chooses due to the mind that has realized the necessity one or another option of the activity. The need that has "entered" the activity loses its eternal determinacy. It turns into another quality and appears as freedom. People possess freedom when external circumstances do not force them to give up their own interests, needs and feelings. Thus, freedom is affirmed in the area of social necessity, but as a result it ceases to be freedom. Knowing the necessity and knowledge of the case is a rather narrow boundary for freedom. Freedom is a wider phenomenon than the cognitive and realized objective circumstances surrounding the person by means of action. The phenomenon of freedom is determined not only by a reasonable active participation in existing forms of human existence, but also by a peculiar creative exit beyond its limits. Since the choice passes through all human existence in society and reveals four domains of public

\footnotetext{
${ }^{2}$ Шинкарук B.I., Яценко О.І. Гуманизм диалектико-материалистического мировоззрения. Киев: Политиздат Украины, 1984. - 255 с. - Ст. 33.
} 
life activity, it is logical to conditionally classify the following fields of life choice:

- Material - a person chooses profession, where to work, searches a personal career of the entire life. There are people who can do any work for living. However, there are other people: they are persistently searching for something that matches their abilities, skills, background. As V. Shubkin emphasizes, "a social person chooses the profession, a spiritual person looks for sense of life ${ }^{3}$;

- Social - a person is determined in the system of socio-political relations, chooses own life position, defends both own and certain social group interests, joins or does not join various political parties and public unions, associations, movements, is engaged in active public-political activity or is separated from it;

- Spiritual - is the most complicated and comprehensive one. This is the choice of education, artistic and moral values, a subject of belief, sense of life etc. The choice of spiritual values is the most complicated because it is the most responsible because a person is governed by own spirituality in life, namely, mind, feelings, and will. The choice has a contradictory nature, because the field of spirituality does not actually have borders, because it includes both fantasy, and dream, and utopia, and belief, and the real spiritual principles of human daily activity. Spiritual choice of personality is boundless. However, there is always one option of choice - good and evil, the truth and lies, the beautiful and the ugly.

These issues are covered by the problem of freedom of conscience, freedom of choice of spiritual and cultural values. These freedoms mentioned are definitely determined by mankind as the original right of personality, to which access of strangers is prohibited. However, how many more martyrs of conscience are in the camps, how many people were burned in the flames of the Inquisition, how many of them were proclaimed state criminals, dissidents, mentally ill. The right to choose spiritual values is affirmed through pain and suffering. However, as it seems to us, mankind will never cede the acquired rights of freedom of spirit self-determination, because it is precisely in this the germ of future, creativity, socio-historical progress takes it origins.

3 Шубкин В. Начало пути. Проблемы молодежи в зеркале социологии. - М.: Молодая гвардия, 1979. - 224 с. 
The latter does not mean that the choice of a system of values does not have determinant factors. A person lives in society, along with them other people exist, live, act, give birth and bring up children possessing the sovereign right to choose spiritual values as well. The situations often arise when one choice encounters the other, one will contradicts another, and one freedom requires realization only through conquest of the other. To overcome and prevent such situation the mankind has invented and formed relevant regulatory mechanisms. The morality is one of the most effective ones.

Morality prompts a person the option of choosing spiritual values and appropriate behavior because it is exactly based on conscience - a moral feeling, in which a person's self-esteem is manifested as correspondence of their actions taken in society in the converted into the conviction of morality norms. In compromising of conscience, a person loses humanity, personality, social significance. Conscience represents all human feelings; it is their "voice" and their "pangs". "Pangs of conscience" turn people into humanity, predetermine the preventing of a wrong choice.

And yet, even conscientiousness is sometimes not enough for the proper choice of sensual life values. J.-P. Sartre describes the situation of choice, when a young man, on the one hand, has to go to protect his homeland from enemies, and on the other - to take care of an old, sick, weak mother who dies without his help. J.-P. Sartre says that each option has the right to exist as the option that is done in conscience. However, having chosen one option, how to act with another? The life experience, folk wisdom, high level of mind, and finally, determination, will and many other things are necessary. As V. Bakshtanovsky writes, in a conflict situation, only moral wisdom, the union of conscience and reason, the unity of requirements of morality and social reasonableness can resist and win $^{4}$.

Personality, their inner world and consciousness do not exist and can not exist outside a specific system of public relations, way of life, situation, coincidence of circumstances, where in combination of contradictory interlacement a person makes one or another choice. The situation of human confrontation and circumstances created by it as hostile to each other manifests itself in "alienation".

\footnotetext{
${ }^{4}$ Бакштановский В.И. Этика как «практичная философия»: традиционные образы и современные подходы. - М.: Политиздат, 1983. - 186 с. - Ст. 15.
} 
Earlier Socrates philosophy did not distinguish morality as a special field, as well as the world order. Space merged into one with the world of the ancient polis, "logos", ruling in it, expressed the idea of the ancient traditional polis relations. But gradually space is beginning to significantly expand the social and spiritual connections that made the Greek a personality relatively independent of local limitations. His selfconsciousness was no longer tied to traditional guidelines; he became capable of judging the laws of human relations and entering into a new worldview by his own mind, but this worldview was rather limited, bearing a personal distinction of the chosen, and, at first, it was happening not so much in everyday consciousness but in philosophical thought. At the same time, philosophy acted not as an esoteric branch of knowledge, but as a vital wisdom, an ideal of social world understanding, where life is in harmony with nature and logos. Philosophy is a part of general education of a spiritually developed personality and on this basis it has come into conflict with the archaic, mythological and traditional worldview. Ancient ethics before Socrates and Plato was a kind of vital guidance in life prudence, teaching about a certain attitude to things, various changes in personal destiny and above all to oneself.

It is these two circumstances, the merger of problems of meaningful life and personal-behavioral in philosophy with the cosmological teachings, on the one hand, and on the other - non-specific widening of the moral problem, as understanding the "virtue" of human benefit in general, matching the moral problem with the universal life teaching, predetermined the coincidence of tasks of a new philosophical worldview and moral formation of personality in early ancient thinking. It is determined by two circumstances: on the one hand, the merger of personality-behavioral problems in the philosophy with cosmological teaching, and on the other - the understanding of "virtue" as a human benefit in general, as well as the development of moral problem in general life teaching. In Democritus, for example, a wise man is an ideal of goodness, acquiring a certain degree and lives accordingly to this degree. A wise philosopher is a man who has not only comprehended the laws of the universe and human life, but has also learned to understand everything that is happening to him, which is the spiritual guideline of the 
philosopher. This is exactly the guarantee of true morality, which makes him strive for "just and legitimate matters".

In early ancient culture, not only ethics merges with philosophy, but also the theory of morality coincides with moral considerations and moral preaching. The philosopher does not consider moral ideas from theorist's side, but he thinks on the logic of moral consciousness as a moral personality, justifying for himself and another people the program of public and political life. And this is a fundamental coincidence of normative and theoretical consideration about what should be and what exists. Democritus deliberately implements the principle of naturalistic interpretation of a person: all that they strive to achieve and what they must strive to achieve is determined by the nature of all living things. Perfect, fair, virtuous - it's just another name of something natural, useful for life that brings health and pleasure. And if so, then preaching goodness is the same as uncovering the nature of space and a person as part of it to people. The philosopher is a real holder of morality; his teaching is nothing more than a moral doctrine of life.

Social philosophy has always faced an ethical problem and the task of justifying evil, an explanation of imperfection of the empirical world, arose from an ideally-perfect beginning. In the very moral consciousness this problem is solved rather easy because a value view on the world mandatory splits the reality in the mutually opposite: good and evil, the beautiful and the ugly, and the determinacy of goodness as a positive value requires its antipode, anti-value. Even Heraclitus and the Stoics clearly emphasized this logic of value consciousness - there would be no goodness without drawbacks, no beauty without ugliness, both are mutually acceptable.

Such understanding of the problem of public and individual life in philosophy and morality allows distinguishing three sides and, accordingly, three different paths, according to which this organically integral, syncretic teaching subsequently developed or split.

First of all, one should note an individualist trend in the Democritus ethics, namely the trend inherent in a number of schools in ancient philosophy. The teaching of life focuses on the personality and is essentially a program of personal self-existence, self-affirmation and

5 Аболина Т.Г. Исторические судьбы нравственности (философский анализ нравственной культуры). - К., 1992. - 196 с. - Ст. 211. 
salvation of an individual. And if Democritus still puts the interests of the state and social justice above all, the Socratics and Stoics completely refuse from the task of organizing and ordering public life, they govern a person only to personal salvation. Ethics is distinguished by Aristotle in a special branch, who constructs it as a teaching of goodness of personality's moralistic qualities. From the Stoics a traditional division of philosophy into three branches is originated: logic, physics and ethics. Such division is also accepted by Kant, who justifies it only as a division between the teachings of method, nature, and freedom of morality. After all, even up to the Modern time, ethics is more often understood as a science about human nature, their principles, and action goals in general. Such a broadening of the subject of ethics derives from interpretation of its tasks. The task of ethics was to teach a person certain rules of life, based on their own natural or divine nature. That is why ethics combined the theory of human existence: ontological, naturalistic or religiouseschatological, the study of emotions of psyche affects and, at the same time, the teaching about ways to achieve a good life: a common benefit, happiness, and salvation. Thus, the pre-Kantian ethics of unity of the being and the proper solved a double problem: an explanation of the real human state in the world, the causes of human actions and the justification of moral principles, guidelines on how to act, that is, united the theoretical and practical philosophy in it.

In German philosophy, the solution of the ethical theory issue has started. The problem was that the morality had not been reduced to psychology or "mechanics", as well as to prudence and "mathematical calculation". That is, morality should reflect a somewhat more perfect and elevated, but not a pressure of natural feelings or practical prediction. It is to this that the moral experience of a person who, in the name of morality, refuses personal interests for the sake of someone's benefit, leads. It is resulted in the fact that morality, due to its uniqueness, is both a domain of primary feelings and norms, because they are given from above and as a result are the essence of a person. Morality is essentially universal, comprehensive in comparison with the empirical determinacy of a person as an individual. Since it is non-natural and does not obey the impulsivity of natural aptitudes, it is necessary to put a question of a definitely specific, other way of moral determination of a person - an essential, but not spiritual-internal and external- material one. Such problems, in its 
essence, are the most difficult points of ethical understanding of morality specificity and they are relevant today.

Among classicists of German philosophy, Kant paid much attention to morality and its specifics; his ethical concept was the most developed and systematic. At the same time he was the most consistent opponent of morality concepts - theories of moral feeling.

The specificity of Kant's morality is in the fact that he sees it, first of all, in the external morality of an ordinary person, if people are taken as they are, in fact, by virtue of their personal deeds and motives by which they are truly governed. It is necessary to approach this matter empirically, take a closer look at the thoughts and desires of people, it is not necessary to be an enemy of goodness, but simply an impartial observer, do not doubt "whether a true goodness exists in the world", although it may be that "there have almost never been actions, truly moral motives implemented, an example of which the world may not have given until now." $"$. Morality can not be a thing that excites a person psychologically by something that creates an internal mechanism of person's natural aptitudes and aspirations. On the contrary, it provides something for a person, requires something from the latter, restricts spontaneously mediated impulses and binds. Therefore, morality is binding, appealing to a person, and not the aspirations or feelings laid down in a person by nature.

Thus, a moralistic premise in nature, a skeptical evaluation of actual human existence from the point of advanced requirements to a person, allows sharpening theoretically the normative, externally psychological nature of morality, distinguishing it from the mechanism of spontaneous spiritual movements given to a person from nature, inherent in empirical, indirectly essential individual.

Problems of morality specific nature in the intuitivism are considered as not related to the nature of everything that exists. Neo-positivists, comparing facts and values, come to the conclusion that it is impossible to justify moralistic judgments. Representatives of existentialism believe that human essence has no general definitions and therefore can not provide a basis for formulating any particular moralistic principles. The issue of morality specific nature in the history of ethical thought sometimes acquired another form: whether the moral activity in its essence is

\footnotetext{
${ }^{6}$ Кант И. Антропология с прагматической точки зрения. - СПб.: Наука, 1999. - 472 с. - Ст. 244-245.
} 
reasonable, serving the implementation of any practical goals and achievement of certain results, whether it is completely unreasonable and appears only as a fulfillment of law, the requirements of a certain absolute existence, preceding any need and goal. This alternative existed in the form of the issue about correlation in morality between the concepts of non-moral and morally appropriate benefit, where it is necessary to determine and justify the concept of benefit. Such approach led to the conception of consequential ethics where moral actions must be chosen and evaluated depending on such practical outcomes to which they led (hedonism, eudemonism, utilitarianism, etc.). This simplified moralistic problem, the motives of action and observance of general principles have become inessential.

Emphasizing the social nature and the purpose of morality, Plato and Aristotle consider it, first of all, as a means of organizing public-political life, but not merely the achievement of personal perfection and bliss. That is why moral teaching and political orientation occupy here a special place and does not cover the whole field of philosophical issues. A human soul, according to Plato, reflects the primary source of matter, the realm of ideas and the conflict between them, but at the same time, this soul with its qualities such as reason, sensuality and will is projected on the construction of a state that generating the state of wise men and rulers, guards-warriors, peasants, craftsmen and slaves. That is why Plato has still no ethics as an especially distinguished discipline, and there is no own theoretical study of what morality is. Wisdom, courage, moderation, justice are not just virtues, moral qualities educating people, but the necessary factors creating natural harmony between people and must be personified in a certain order that will be necessary for the future in order to build society. Plato remains a moralist in philosophy. He anthologizes moralistic qualities and thus defends the point of view of the very moral consciousness, absolutizing and fetishizing his concepts. For him there is no clear line between the philosophical study of the existing and the moral justification of such ideal that he defends. In the future, this is a typical feature of medieval consciousness.

Aristotle had another approach to the study of morality, whose ethics is rather separated field of study. He was the first who mentioned the subject of ethics - the study of goodness, goals and benefits of a person; considered this subject as a theoretical task, that is, he approached 
morality not as a moralist, but as a scientist and researcher. The historical split of two ways of thinking about the world of moral and philosophical vision has begun from him. In ethical teaching Aristotle is the first who theoretically distinguishes a person from the realm of nature and insists that a person has a specific, public nature. And then he clearly divides two functions of thinking - theoretical and practical, namely, moral and ethical, and this proves that ethics - the science about the practical action of a social person - can not coincide with the general ontology, cosmology, or metaphysics.

Aristotle emphasizes that the very concept of goodness is normative; goodness is socially acquired and approved "acquired qualities of the soul"'7.

He argues that goodness is not given to a person from nature, but is cultivated in it by purposeful action and exercises, therefore, ethics can not be just a teaching of the human nature, but is a science about the normative, the educated and the appropriate in human behavior. Aristotle sometimes defines the freedom of person's will, such a mental and anthropological ability, provided by nature through the moral concepts of responsibility, approval, and guilt. $\mathrm{He}$, for example, indicates that a human act is voluntary or involuntary, depending on whether the act is punishable or not. In other words, he seems to introduce the concept of "free will" in the limit of morality itself, thus he excludes the possibility of direct derivation of morality from the very general concept of "a person", which is urgent to modern researchers of the theory of morality as well. Philosophers of later eras considered freedom of will as a natural or supernatural precondition of morality.

Aristotle is the first in ethics who raises the problem of freedom of choice, distinguishing morality from other ways of social regulation. It is also typical how he poses and solves this problem. It seems that the freedom of will is, first of all, the ability inherent in people as they are, they anthropological and psychological feature. Only in such a way the question of freedom of will is further resolved by many philosophers. Aristotle begins his reflections from the other side. Whether a person is free or not free in choosing one or another action depends on how society treats such actions. If it approves or blames such actions, then, accordingly, they are in person's responsibility, considered as person's

\footnotetext{
${ }^{7}$ Аристотель. Політика. - К.: Основи, 2003. - 239 с. - Ст. 88.
} 
merit or guilt, that is why these actions are voluntary, free. Thus, he is the first who posed the very problem of freedom of choice and, at the same time, the first who solves the issue on the specificity of morality as social relations. Freedom of will is not a person's ability, although in a new time the majority of philosophers will solve the issues this way, seeing in freedom of will a certain natural or supernatural precondition of morality, and a phenomenon arising within the limits of morality as a means of regulating human activity.

Thus, Aristotle has already rather clearly defined specific features of morality, distinguished the most typical and peculiar features, the most significant moments, which makes it possible to distinguish ethics in a specific theoretical discipline. All these moments mentioned in Aristotle's ethics, expressed with a different share of consistency and precision, allow making a conclusion about the beginning in the division of general philosophical and moral views; the morality are now perceived as a specific field of human thought.

In ancient times, from Democritus to the Stoics, philosophy was a direct coincidence with the personal life program and the attitude of a person- philosopher. Starting from Aristotle and Plato, ancient philosophy became like a professional, special mental activity, different from the human way of life and feelings. The personalities of Democritus, Socrates, Aristippos of Cyrene, Diogenes of Synod, Crates and Hipparchia, Epictetus and Epicurus, and many others in all their specificity of life manifestations served as a living reflection of the relevant philosophical theses. For a "wise man" there was no difference between his teaching and personal existence. And it is not about archaic syncretism and inseparability of ideas and actions inherent in ancient culture at all.

During the Enlightenment there was a criticism of morality in the practical field of activity and religious morality. It was accused of replacing such a moral vision, not capable of self-evidence and holiness, with explanation of the world as a whole, based on a natural basis and subordinated to the naturalistic worldview. There was a modification of the priority of religious and moral world perception, moral significance of phenomena received status only from the point of view, which was reduced to the natural substance and originated from it. Hence it appears that philosophy should consider the world not from the point of view of the categories of good and evil, but to bring moral concepts to the 
corresponding natural science dogma. While philosophy is a true worldview, morality is the same in a relative measure. Morality is a worldview when it agrees with scientific philosophy, although, recognizes the lack of absolute truth and independence.

For the ethics of the 17th century, the consolidation of concepts of good and evil to anthropology and psychology is typical. It came from the fact that the idea of goodness and drawbacks, relevant motives and stimuli are inherent in the very essence of human nature, as well as the spiritual level of a person. Such a point of view is expressed in Descartes' reflections on the specifics of morality in the clearest way, in particular, in the work "Passions of the Soul". Conscience, repentance, love and respect, shame and pride, courage and cowardice, badness and nobility, goodness and drawbacks are defined as the properties and manifestations of the universal mental structure of a person, as the expression of primary emotional impulses, as the result of correlation and measure in each individual.

Descartes does not go further than natural and scientific explanation of the traditional content of morality specificity concept; he conducts such reduction of morality to the psycho-anatomical, natural phenomenon, resulted in impossibility of solving the issue of the morality specificity, its non-reduction to other person's attributes. Spinoza goes further than Descartes in this breaking of illusion about the uniqueness and selfprobability of moralistic concepts.

Feeling himself as a monistic materialist, he put the question of the status of moral concepts and characteristics in a purely metaphysical plane of consideration at the very beginning, although the analysis of human affects and relevant withdrawal of moral phenomena from the psyche also occupies an important place. Yet in his early work, "Short Treatise on God, Man and His Well-Being", Spinoza claims that good and evil are only the essence of human thinking that they are absent in nature, in which everything exists and occurs by the necessity only. In this regard, he even rejects some traditional ideas of a virtuous person. Repentance of conscience, confession, honor and shame, affection and gratitude are all the manifestations of people's imperfection. A truly intelligent person should be guided only by the cognition of necessity and love for the truth, and never by sadness and other affects. Specifying his attitude to moral ideas, Spinoza demonstrates a clear criticism of morality, and at the same time the aestheticization of nature in "Ethics". Spinoza describes as ideas 
the means for the interpretation of natural phenomena, the concept of good and evil, sin and merit, the perfect and the imperfect, the beautiful and the ugly. "All the ways, which usually explain the nature, are only different kinds of ideas and do not show the nature of any thing, but only the state of ability of ideas. ${ }^{8}$

Englishman Thomas Hobbes, contemporary of Descartes and Spinoza, considers the specificity of morality from the point of habits and aptitudes of human behavior and the arrangement of public life. This understanding takes place in three distinct levels, resulting in three different concepts of morality. In the first case, goodness is inherent in people in their natural state or in every person in relation to their individuality, directly inherent in their nature only. Customs, from this point of view, are determined by firmly rooted habits of behavior. "If the customs are virtuous, they are called goodness, but if they are bad, they are with drawbacks". Good and evil are just "names given to things", which are essential for people in their receptivity or non-receptivity in the evaluation of objects. Due to the differences in temperaments, habits and attitudes of people, the concepts of good and evil are relative, individually distinct and enter into arguments with each other. In the natural state there can be no general derivation of a single evaluation of goodness and drawbacks as well as there can be no "science about morality". In the perception of goodness only personal individual benefit is expressed, such concepts as courage, moderation, prudence create the basis, first of all, for the interest of an individual, but not the public whole.

Due to the fact that people "measure good and evil by different measures, the state of war appears between them" "10. The only scale of measure of goodness and drawbacks is established only in the state due to the laws established in it.

Goodness in this case is an expression of personal aspirations and usefulness, determined by the usefulness of state and thus gets the status of justice. "Good customs, that is, moral goodness, are such customs, through which the state organization once established can be preserved in the best way." 11 . It serves as the basis for creating another concept of

\footnotetext{
8 Філософський словник соціальних термінів / Склад. та упоряд.: В.П. Андрущенко, М.I. Бойченко, М.I. Михальченко; під заг. ред. В.П. Андрущенка. - Київ, 2002. - 672 с. - Ст. 400.

${ }^{9}$ Гоббс Т. Избранные произведения в 2 т. - М.: Мысль, 1964. - 748 с. - Ст. 260.

${ }^{10}$ Там же. - Ст. 261-262, 338-339.

${ }^{11}$ Там же. -748 с. - Ст. 262.
} 
morals and morality as a specific public institution. But Hobbes understands human sociality through the concept of a social agreement and, therefore, it is identified with statehood. As a result, morality in its essence is reduced to a legal law, and the grounds and formation of moralistic demands for an act of legislation, goodness in turn to subordination to the law. Morality from this point of view has no own field of activity, it has a place only in institutional, official statutory establishments. However, the laws of state, established by the will of a legislator, are nevertheless relative and may have various meaning in different states. From this point of view, "whatever those laws would be, it is the obedience to them that is goodness, and violation of them is a drawback. And even if the actions provided by laws can be very different, justice is obedience to the laws, unchanged and it stays the same."12. That is, only the fact of obedience to the law is important, regardless of the meaning of relevant actions. Thus, the laws of the state and society are not imagined at all, but derive from the natural needs of public life and interrelations. "Natural laws are not laws provided by the state; they exist before the state will, because they are originated from the nature itself."13. Such laws are revealed not only to the state mind, but to the "Mind which is a natural law, directly given to any person by God as a measure of their actions" ". Natural laws but not the laws proclaimed by the state "create the essence of moral philosophy", 15

The transition from socio-state integration of morality to its naturalistic understanding allows Hobbes to define moral laws as general, such laws that have a fundamental basis that is the origins from the very nature of things. But these laws acquire abstract, not purely moral content. But these laws acquire abstract, not purely moral content. Natural laws include everything attributed by mind - "what should be done and from what is necessary to keep away". ${ }^{14}$ It is possible to attribute the useful and purely moral to them, that is, those moralistic provisions, as well as those imperatives that restrict personal interest.

So, Hobbs has three different concepts of morality. The fist one reduces morality to psychology of individuals and explains why people exactly tend to act in one or another way, explaining this by their

\footnotetext{
${ }^{12}$ Гоббс Т. Избранные произведения в 2 т. - М.: Мысль, 1964. - 748 с. - Ст. 261.

13 Там же. - Ст 340.

14 Там же. - Ст 341.

15 Там же. - Ст 338.
} 
temperament peculiarities, natural aptitudes and aspirations. The second one reduces morality to the state organization needs and explains why it is necessary, in general, for people to agree their actions in the field of public life. Here morality serves as a set of "technological" rules in relation to the purposeful order of society. The third concept of specificity of morality emphasizes the "normative and provisional nature of moral requirements: that is something to what an intelligent nature binds a person" 15 . However, these requirements are not social any more, they are united with the nature of the world order. In any case the sufficient understanding of specificity of morality has not achieved. Later on, all three different level concepts of morality, namely moral as a psychological mechanism of behavior, as social purposefulness and as manifestation of universal nature merge in a single whole creating synthetic morality institution as something identical with anthropology. Much later, when the philosophy of modern times was separated in an individual field from the everyday life, the idealist thinker Soeren Kierkegaard strongly criticized a way of philosophizing "liberated" from the life and personal existence and opposed it with existential, personalarranged thinking, as an example of a truly philosophical consciousness. On the one hand, Ludwig Feuerbach raised the same problem in philosophy, maximizing its ascending and final results to the activity and sensibility of an empirical person. Thus, the remoteness of philosophical thinking from the field of practical action repeatedly was denied and defended from the very positions in the history of philosophy itself.

On the other hand, moral form of consciousness was reduced to indirect practical guideline not in all manifestations requiring certain actions from a person in life situations. Of course, the social function of morality, first of all, is in the regulation of human actions and relationships. But it is the practical-regulatory purpose of morality that increases to the general worldview function, to the image of general picture of the human world not only within its ideal boundary, but also in the real general historical movement, in the struggle of good and evil, or in the process of approaching the ideal. And the point here is not only that moral principles and norms due to their general nature should have a qualitative foundation, such as the postulate of person's "purpose". And not even because the order of proper things required the creation of an idea of a certain essential beginning from which they arise, because they 
have an objective will of a person, independent of the subjective. The point is also that moral truths do not match with simple commandments: do not kill, do not steal, tell the truth, and come into conflict with the existing conditions and the limited possibilities of social organization of society. The unconditional and complete fulfillment of these commandments in the moral consciousness of people was more often postponed to the future or transferred to another, ideal world, and moral truths acted as a means of thinking of a moral personality who is in conflict with the world and never with oneself, with something that forces and gets interested an individual to do every day for self-protection. Under these conditions, some moral ideas keep their normative-mandatory meaning to serve not only to the definite instructions for action. The ideals of moral consciousness were moving away from direct life practices, because their performance deviated from the real possibilities and specific-situational needs of social reality. Due to this conflict between the proper and the existing there are ideas of absolute good, universal justice, the idea of a moral ideal as something far from a reality of life.

The founder of philosophical hermeneutics W. Dilthey proceeds from the fact that consciousness includes three relatively independent layers: objective (reproduces reality), emotional (reflects the attitude of a person to this picture) and the will, in which emotional evaluations acquire the form of impulses, aimed at transformation of reality. The emotional layer of consciousness forms the basis of human activity. Today, scientists are increasingly experiencing the insufficiency of past approaches and the necessity for research of internal psychological, worldview, ethical and moral orientations and motivations of individuals, social groups and layers.

Therefore, the problem of universal basis arises in the moral consciousness not only as a reflection of necessity for generalization of personal norms, their reduction to a single denominator, to something objectively substantive, but as a practical issue of possibility of implementing these norms. It is due to the conflict and contradictory nature of this issue that the universal postulates of morality are detached from those real conditions and public relations, being their expressions in the minds of moral subjects. 


\section{REFERENCES}

1. Копнин П.В. Гносеологические и логические основы науки. М.: Мысль, 1974. - 565 с.

2. Шинкарук B.I., Яценко O.I. Гуманизм диалектикоматериалистического мировоззрения. Киев: Политиздат Украины, 1984. -255 с. - Ст. 33.

3. Шубкин В. Начало пути. Проблемы молодежи в зеркале социологии. - М.: Молодая гвардия, 1979. - 224 с.

4. Бакштановский В.И. Этика как «практичная философия»: традиционные образы и современные подходы. - М.: Политиздат, 1983. - 186 c. - СТ. 15.

5. Аболина Т.Г. Исторические судьбы нравственности (философский анализ нравственной культуры). - К., 1992. - 196 с. Cт. 211.

6. Кант И. Антропология с прагматической точки зрения. - СПб.: Наука, 1999. - 472 с. - Ст. 244-245.

7. Арістотель. Політика. - К.: Основи, 2003. - 239 с. - Ст. 88.

8. Філософський словник соціальних термінів / Склад. та упоряд.: В.П. Андрущенко, М.І. Бойченко, М.І. Михальченко; під заг. ред. В.П. Андрущенка. - Київ, 2002. - 672с. - Ст. 400.

9. Гоббс Т. Избранные произведения в 2 т. - М.: Мысль, 1964. 748 c. - Ст. 262.

Information about the author: Tymoshenko T. S.

Candidate of Philosophical Sciences, Assistant Professor at the Department of Philosophy and History Educational-Scientific Humanitarian Institute V. I. Vernadsky Taurida National University, 33, Ivana Kudri str., Kyiv, 01042,Ukraine. 